\title{
SOCIAL MEDIA AND SPORT CONSUMPTION: THE EFFECT OF TEAM IDENTIFICATION ON ATTITUDE AND BEHAVIORAL INTENTION
}

\author{
Mohammad Salari \\ Master in Sport Management, Lecturer in Faculty of Human Science \\ Jiroft University/ Jiroft, Iran \\ m.salari@ujiroft.ac.ir \\ Mohammad Mazyari \\ $\mathrm{PhD}$ in Sport Management from University of Tehran \\ m.mazyari@yahoo.com
}

\section{ABSTRACT}

Objective: This study aimed to investigate the effect of team identification on attitude towards social media and behavioral intention based on social media.

Methodology / Approach: This is survey research. The target population consisted of physical education and sport science students of the University of Tehran, IRAN. In the end, 185 surveys are returned and analyzed. Team identification was measured by Heere et al questionnaire (2011), attitude towards social media was measured by Cretti's questionnaire (2015) and Lin et al questionnaire (2009), and, consequently, behavioral intention was measured by Phonthanukitithaworn and Sellitto questionnaire (2017). furthermore, the questionnaire's face validity was investigated according to some field-specialist sport management scholars. Structural Equation Modeling and SmartPLS software were used to analyze the data.

Originality / Relevance: The study was necessary due to the lack of similar studies to investigate the use of social media in the sport context by students in IRAN. Also, the relationship between the same variables has not previously been studied.

Main results: The results showed that team identification has a positive and significant effect on attitude towards social media and behavioral intention based on social media. Also, the attitude towards social media has a positive and significant effect on behavioral intention based on social media.

Theoretical / methodological contributions: To increase behavioral intention based on social media in the sport domain it is essential to consider the team identification and attitude towards social media.

Keywords: Social Media. Sport Consumption. Attitude. Behavioral Intention. Team Identification

\section{$\underline{\text { Cite como }}$}

American Psychological Association (APA)

Salari, M., \& Mazyari M. (2020). Social media and sport consumption: the effect of team identification on attitude and behavioral intention. PODIUM Sport, Leisure and Tourism Review, São Paulo, 9(2), 199-213. https://doi.org/10.5585/podium.v9i2.13838. 


\section{MÍDIAS SOCIAIS E CONSUMO ESPORTIVO: O EFEITO DO ATRIBUTO SEMELHANTE COM A EQUIPE NAS ATITUDES E INTENÇÕES COMPORTAMENTAIS}

\section{Resumo}

Objetivo do estudo: O objetivo deste estudo foi investigar o efeito de atributo semelhante com a equipe sobre atitudes em relação às mídias sociais e intenções comportamentais baseadas nas mídias sociais.

Metodologia / Abordagem: Este é um estudo de pesquisa. A população estatística inclui estudantes de educação física e ciências do esporte da Universidade de Teerã, no Irã. Finalmente, 185 questionários foram devolvidos e analisados. Atributo semelhante com a equipe utilizando o questionário do Heer and et al (2011), Atitudes em relação às mídias sociais usando os questionários Cretti (2015) e Lin et al. (2009) e intenções comportamentais usando o questionário do Phonthanukitithaworn e Sellitto (2017), foram medidas. Além disso, a validade de face dos questionários foi confirmada pelos professores de gestão esportiva. Para análise dos dados, foram utilizados modelagem de equações estruturais e o programa do SmartPLS.

Originalidade / Relevância: Este estudo foi necessário devido à falta de um estudo parecido que examina o uso das mídias sociais no campo do esporte por estudantes no Irã. Além disso, a relação entre essas variáveis ainda não foi estudada.

Principais resultados: Os resultados mostraram que a atributo semelhante com a equipe tem um efeito positivo e significativo nas atitudes em relação às mídias sociais e nas intenções comportamentais baseadas nas mídias sociais. Além disso, atitudes em relação às mídias sociais têm um efeito positivo e significativo nas intenções comportamentais baseadas nas mídias sociais.

Contribuições teóricas / Metodológicas: Para aumentar as intenções comportamentais baseadas nas mídias sociais no campo do esporte, é necessário prestar atenção a atributo smelhante da equipe e à atitude em relação às mídias sociais.

Palavras-chave: Mídias Sociais. Consumo Esportivo. Atitude. Intenções Comportamentais. Atributo Semelhante com a Equipe.

\section{LAS REDES SOCIALES Y EL CONSUMO DEPORTIVO: EL EFECTO DE LA INTEGRIDAD CON EL EQUIPO SOBRE LA ACTITUD E INTENCIONES COMPORTAMENTALES}

\section{Resumen}

Objetivo de estudio: El objetivo de esta investigación era revisar el efecto de la integridad con el equipo sobre la actitud hacia las redes sociales e intenciones comportamentales basado a las redes sociales.

Metodología / Enfoque: Esta es una encuesta de investigación. La población estadística incluía los estudiantes de la Educación Física y la Ciencia Deportiva de la universidad de Teherán. Al final, 185 cuestionarios se habían devuelto y se pusieron a analizarlo. La integridad con el equipo fue medido por el cuestionario de Heer y compañeros (2011), la visión hacia las redes sociales fue medida por el cuestionario de Cretti (2015), y Lin y compañeros (2009), y las intenciones comportamentales fueron medidas por el cuestionario Phonthanukitithaworn y Sellitto (2017). También, el aparente valides de los cuestionarios fue confirmado por los profesores de gestión deportiva. El modelado de ecuación estructural y el software SmartPLS, se usó para el análisis de los datos. 
Originalidad / Relevancia: Esta investigación era necesaria, por no haber existido otra investigación similar, que revisara el uso de las redes sociales en el campo del deporte por los estudiantes en Irán. Aparte de esto, la relación entre estas variables no se había estudiado antes.

Resultados principales: Los resultados demostraron que la integridad con el equipo tiene un efecto bueno y significativo, sobre la actitud relativa a las redes sociales y los conductos basado en redes sociales. También la visión hacia las redes sociales, sobre los conductos basados en las redes sociales tiene un bueno y significativo efecto.

Contribuciones teóricas y metodológicas: Para aumentar las intenciones comportamentales basado a las redes sociales en el campo del deporte, se requiere poner más atención sobre la integridad con el equipo y la actitud hacia las redes sociales.

Palabras claves: Redes Sociales, Consumo Deportivo, Actitud/Visión, Intenciones Comportamentales, Integración Con El Equipo.

\section{Introduction}

Social media has attracted the attention of many scientists and specialists due to its inclusiveness and cultural effects. The recent improvements in technology and the emergence of social media have had a profound effect on sports consumption by people (Filo, Lock \& Karg, 2015). In addition, social media can act as an interactive channel between sports and individuals. This idea is being used increasingly for relationship marketing and product consumption (Phonthanukitithaworn \& Sellitto, 2017). Consumers can use social media in various stages of the consumption process; including information search, decision-making, word of mouth, and the purchase, use, and disposal of products and services (Filo, Lock \& Karg, 2015). In the field of sports, Filo et al. (2015) have defined social media as "new media technologies facilitating interactivity and co-creation that allow for the development and sharing of user-generated content among and between organizations and individuals". In addition, sports consumers can simultaneously use social media as a channel to communicate and interact with others through the internet while watching live sports events (Billings, Qiao, Conlin \& Nie, 2017). Live sports broadcasts lead to the excitement of viewers, which can potentially motivate people to use social media as an expressive and interactive tool during the television broadcast (Lim, Hwang, Kim \& Biocca, 2015). Interactions in this situation reflect a form of sports consumer participation, which creates advantages for individuals such as: searching for required content or expressing personal viewpoints while associating with the online society (Billings, Qiao, Conlin \& Nie, 2017; Lim, Hwang, Kim \& Biocca, 2015). 
In the field of sports, managers put a lot of time and effort into different marketing activities with the purpose of attracting supporters for participation in various consumer behaviors, such as stadium attendance and purchasing the team's promotional products; because the most significant factor in the financial success of every sports organization is the formation and constant commitment of a group of passionate supporters (Katz, Ward \& Heere, 2018). Team identification is one of the psychological structures that relies on structural environments and social relations. Team identification counts as a key factor for the loyalty of the supporters (Cunningham \& Eastin, 2017). Within this framework, team identification is defined as "individual orientation towards other things -including a group or another individual- which results in close emotional dependency or feelings" (Trail, Fink \& Anderson, 2003). Individuals prefer to be identified within a group with traits similar to their own, that commits them to do activities that support the group (Cunningham \& Eastin, 2017). Therefore, team identification has a significant effect on persistent behaviors in sports environments; such as watching the games on television and participating in discussions regarding the team (Trail, Fink \& Anderson, 2003). Team identification is defined as the individuals' perception of the relationship between them and the sports team, in a way that makes them regard the team's successes and failures as their own personal experiences (Ashforth \& Mael, 1989). Researchers have established that team identification has a positive effect on the supporter's consumption intention (Gray \& Wert-Gray, 2012; Heere et al. 2011; Song \& Ryu, 2016). Sports consumers with high team identification support their team with their presence even when the team performs poorly (Wakefield \& Sloan, 1995). Behavioral tendencies under the influence of team identification often yield positive results such as increased attendance in the game, tendency to purchase the team's apparel, and higher media consumption (Heere et al. 2011; Song \& Ryu, 2016; Wakefield \& Sloan, 1995).

Furthermore, various researches have addressed the role of social media in sports consumption and sports marketing. For instance, Moyer, Pokrywczynski \& Griffin (2015) have found a positive relationship between team identification, using the team's Facebook page, and purchasing the team related products. Similarly, Suh, Ahn \& Pedersen (2013) have established that team identification has a significant and positive effect on satisfaction and revisit to sports websites. Based on these findings, high team identification is necessary for the supporter's return and establishing a continuous relationship between the supporters and the team. Therefore, sports fans with high team identification are very likely to have a positive attitude 
toward using social media. They visit the sports teams' websites, pages, and channels through their smartphones or tablets, and interact with other individuals by reading articles, providing content, and expressing their opinions (Cunningham \& Eastin, 2017). For example, Cunningham \& Eastin (2017) have established that team identification has a positive relationship with the attitude toward using second screen devices such as smartphones, tablets, etc.

Moreover, the attitude of sports consumers can form their behavior and lead to participation. Various approaches can explain the behavioral intentions of individuals to accept and use social media in the field of sports. It is evident that the individual's voluntary behavior for verification is important for the acceptance of social media among sports consumers (Phonthanukitithaworn \& Sellitto, 2017). Supporters with high team identification tend to participate in groups to which they belong to, and have more cooperation with the other members of the group (the other supporters) (Cunningham \& Eastin, 2017). Therefore, supporters with high team identification probably use social media to express their support of their team or favorite player and communicate with other fans. The individual's positive experience in using social media leads to a positive attitude towards it (Park \& Dittmore, 2014). A problem that still exists in sports organizations -specifically in sports clubs in Iran- is the inadequate and improper use of the capacity of social media for revenue generation, attracting supporters, and product and service marketing. Therefore, a factor such as the attitude towards social media and its role on the behavioral intentions of sports fans is important to discuss and study when using social media.

In addition, based on the findings of Mudrick, Miller \& Atkin (2016), social media is an effective society that forms the attitude and beliefs of sports fans. It is obvious that watching a game or a sports event on TV is not a linear activity anymore; because social media allows a simultaneous access to a large amount of information, statistics, live results, replays, and messages; which potentially provides a more thorough and satisfying experience for individuals (Phonthanukitithaworn \& Sellitto, 2017). Therefore, a better perception of the activities of sports television program viewers that use social media provides an important insight into the participation and behavior of supporters, which requires more research and evaluation. Furthermore, previous researches on team identification have often used unidimensional scales to evaluate it (Moyer et al. 2015; Song \& Ryu, 2016), which have a lower predictive power than multidimensional scales (Heere et al. 2011). Thus, using a multidimensional scale to better 
evaluate team identification seems a necessity which is taken into account in this research. Accordingly, due to the increasing use of social media in Iran and the background it provides for marketing and advertising, it is specifically important to examine its role in sports consumption. Therefore, the effect of team identification on the attitude toward using social media and the behavioral intentions based on social media in the field of sports are studied in this research.

\section{Method}

This is a survey research. The statistical population of the research consists of the physical education and sports sciences students of the University of Tehran, IRAN. The surveys are designed with a web-based electronic method (Google Docs) and distributed through Telegram, which is a social media app. In the end, 185 surveys are returned and analyzed. The demographic characteristics of the sample are plotted in Table 1. As can be seen, $38.4 \%$ of the individuals are female and $61.6 \%$ are male; $29.7 \%$ are in the age range $18-22,25.9 \%$ are between 23-27, $17.3 \%$ are between 28-32, and 27\% are older than 32 years old. Also, $11.9 \%$ of the individuals use social media less than 1 hour, $31.4 \%$ between $1-2$ hours, $32.4 \%$ between 23 hours, and $24.3 \%$ use it more than 3 hours per day.

Table 1 - Demographic characteristic of the study sample

\begin{tabular}{|c|c|c|c|}
\hline \multicolumn{2}{|c|}{ Demographic characteristic } & \multirow{2}{*}{$\begin{array}{c}\mathbf{n} \\
71\end{array}$} & \multirow{2}{*}{$\begin{array}{c}\% \\
38.4\end{array}$} \\
\hline & Female & & \\
\hline & Male & 114 & 61.6 \\
\hline \multirow{4}{*}{ Age } & $18-22$ years & 55 & 29.7 \\
\hline & $23-27$ years & 48 & 25.9 \\
\hline & $28-32$ years & 32 & 17.3 \\
\hline & Up 32 years & 50 & 27.0 \\
\hline \multirow{4}{*}{$\begin{array}{l}\text { Social media usage in a } \\
\text { full day }\end{array}$} & Under 1 hour & 22 & 11.9 \\
\hline & $1-2$ hours & 58 & 31.4 \\
\hline & $2-3$ hours & 60 & 32.4 \\
\hline & Up 3 hours & 45 & 24.3 \\
\hline
\end{tabular}

Source: The results of the study. 
These surveys are used to collect the data. The team identification survey of Heere et al. (2011) includes 18 items and is marked based on the Likert scale (1= strongly disagree; 5= strongly agree). This survey measures the components of private evaluation (3 items), public evaluation (3 items), interconnection of self (3 items), sense of interdependence (3 items), behavioral involvement ( 3 items), and cognitive awareness ( 3 items). The reliability of the components of this survey is reported to be between 0.86 and 0.94 (Heere et al. 2011). The questionnaires on attitude toward social media by Cretti (2015) and Lin, Gregor \& Ewing (2009) have 6 items and are marked based on the Likert scale ( $1=$ strongly disagree; $5=$ strongly agree). The reliabilities of these questionnaires are 0.84 and 0.85 (Cretti, 2015, p. 27; Lin, Gregor \& Ewing, 2008). The behavioral intentions survey by Phonthanukitithaworn \& Sellitto (2017) has 4 items and is marked based on the Likert scale (1= extremely low; $5=$ extremely high). The reliability of this questionnaire is reported to be 0.87 (Phonthanukitithaworn \& Sellitto, 2017). The face validity of the questionnaires is confirmed by sports management scholars. Their construct validity and reliability is also examined and explained in detail in the results section. The structural equations modeling method and the SmartPLS.2 software are used for the model test.

\section{Results}

During the model test with SmartPLS software, the construct validity, reliability, and measurement tools are also studied. Fornell \& Larcker (1981) have proposed three methods to evaluate the reliability: 1 . the factor loading of each item; 2 . the composite reliability (CR) of each construct; 3. the average variance extracted (AVE). Factor loadings equal to or higher than 0.5 for each item imply good structure. The acceptable level for Cronbach's alpha and composite reliability is 0.7 or higher. Also, the average variance extracted should be equal to or higher than 0.5 ; which means that the studied construct should explain $50 \%$ or more of the variance of its indices. The values obtained for these indices imply an acceptable reliability for the measurement tools (Table 2 and Table 3 ). 
Salari, M., \& Mazyari M. (2020). Social media and sport consumption: the effect of team identification on attitude and behavioral intention

Table 2 - Factor loadings of the measurement items

\begin{tabular}{cccccccccc}
\hline \multicolumn{3}{c}{ Team Identification } & & \multicolumn{2}{c}{ Attitude } & \multicolumn{2}{c}{$\begin{array}{c}\text { Behavioral } \\
\text { Intention }\end{array}$} \\
\hline Item & loading & Item & loading & Item & loading & Item & loading & Item & loading \\
\hline PR1 & 0.76 & I1 & 0.66 & BI1 & 0.78 & A1 & 0.55 & BIN1 & 0.88 \\
\hline PR2 & 0.80 & I2 & 0.77 & BI2 & 0.79 & A2 & 0.66 & BIN2 & 0.90 \\
\hline PR3 & 0.80 & I3 & 0.78 & BI3 & 0.72 & A3 & 0.76 & BIN3 & 0.83 \\
\hline PU1 & 0.64 & SI1 & 0.60 & CA1 & 0.72 & A4 & 0.72 & BIN4 & 0.78 \\
\hline PU2 & 0.53 & SI2 & 0.53 & CA2 & 0.80 & A5 & 0.76 & & \\
\hline PU3 & 0.63 & SI3 & 0.59 & CA3 & 0.72 & A6 & 0.72 & & \\
\hline
\end{tabular}

Source: The results of the study.

Table 3 - Reliability analysis of the measurement tools

\begin{tabular}{lccc}
\hline Variables & Cronbach $\alpha$ & CR & AVE \\
\hline Team Identification & 0.93 & 0.94 & 0.50 \\
\hline Attitude & 0.79 & 0.85 & 0.50 \\
\hline Behavioral Intention & 0.87 & 0.91 & 0.73 \\
\hline
\end{tabular}

Source: The results of the study.

Regarding construct validity, Fornell \& Larcker (1981) suggest that the square root of average variance extracted for each variable should be higher than the correlation between that variable and the others. This means that the correlation of each hidden variable and its indices should be higher than the correlation of that variable with other variables. The square root of average variance extracted is plotted at the end of each row in Table 4. It can be seen that the values associated with each variable are higher than the correlation of that variable with other variables; which shows the acceptable validity of the measurement tools. 
Table 4 - Mean, standard division, correlation and squared AVE

\begin{tabular}{lccccc}
\hline & Mean & SD & $\mathbf{1}$ & $\mathbf{2}$ & $\mathbf{3}$ \\
\hline $\begin{array}{l}\text { 1. Team } \\
\text { Identification }\end{array}$ & 2.966 & 0.787 & $\mathbf{0 . 7 0}$ & & \\
\hline $\begin{array}{l}\text { 2. Attitude } \\
\begin{array}{l}\text { 3. Behavioral } \\
\text { Intention }\end{array}\end{array}$ & 2.466 & 1.044 & $0.298^{* * *}$ & $\mathbf{0 . 7 0}$ & \\
\hline $\begin{array}{l}\text { Source: The results of the study. } \\
\text { S.274 }\end{array}$ & 0.717 & $0.564^{* * *}$ & $0.339^{* *}$ & $\mathbf{0 . 8 5}$ \\
\hline
\end{tabular}

Figure 1 -The tested model in this research

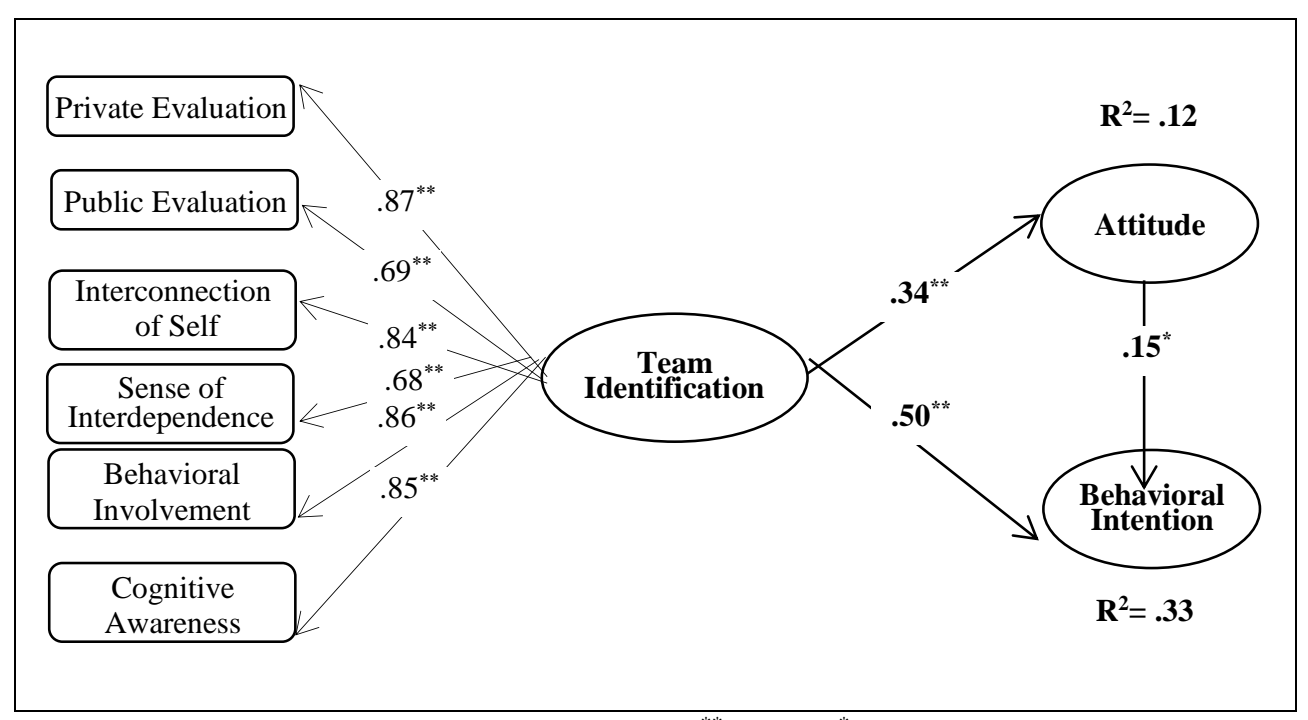

Source: Results of structural equation model. $\quad{ }^{* * *} \mathrm{p}<0.01,{ }^{*} \mathrm{p}<0.05$.

Figure 1 illustrates the tested model in this research. As can be seen, team identification has a significant and positive effect on attitude toward social media $(\beta=0.34, \mathrm{t}=4.69)$, and behavioral intentions based on social media $(\beta=0.50, t=10.51)$ in the level of 0.01 . Attitude toward social media has a significant and positive effect on behavioral intentions based on social media $(\beta=0.15, \mathrm{t}=2.15)$ in the level of 0.05 . In addition, the indirect results indicate that attitude toward social media has a significant partial mediator role between team identification and behavioral intentions based on social media $(\beta=0.05, t=2.13)$. Also, the coefficients of determination $\left(R^{2}\right)$ indicate that $12 \%$ of the changes in attitude toward social media is explained by team identification, and $33 \%$ of the changes in behavioral intentions based on social media is explained by team identification and attitude toward social media. Furthermore, the $Q^{2}$ index is 0.05 and 0.23 respectively for attitude toward social media and behavioral intentions based 
on social media. Since these values are higher than zero, they indicate the total predictive power of the model for the relationship between the variables.

\section{Discussion}

Nowadays, social media is useful for communicating with supporters. Teams and athletes may use social media to encourage or react to various team events in terms of performance or logic. Also, supporters with high team identification use social media as a tool to exchange information about the teams and athletes (Pradhan, 2017, p. 51, 136).

The research results indicate that team identification has a significant and positive effect on attitude toward social media. This result is consistent with Cunningham \& Eastin's research (2017). Since attitude is a psychological tendency associated with prejudice, it provides the means to positively or negatively evaluate individuals. This evaluation yields answers that represent specific opinions about attitude. These opinions are conceptual beliefs that show the individual's attitude toward characteristics, results, goals, and values. The specific performance of an attitude is the symbolization and personal self-concept expression through team identification with prominent reference groups (Madrigal, 2001). So, individuals tend to have optimal attitudes toward subjects that consider the important aspects of their identity to be positive, and also support institutes that illustrate these identities (Ashforth \& Mael, 1989). Therefore, individuals that have a sense of team identification with their favorite team tend to show their support in different ways, media consumption being of them; in a way that team identification develops through the media and team awareness is considered as a key factor in team identification. Since social media increases team awareness, it makes sense to develop team identification using social media (Park \& Dittmore, 2014). In addition, many pieces of proof indicate that there is a relationship between media consumption and team identification. Gau, James \& Kim (2009) have established that a group of individuals with high team identification have higher media consumption (print media, television, and internet) in comparison to individuals with low team identification. Therefore, a high consumption rate of social media, providing and reading content, giving opinions, and participating in discussions regarding the team on social media can lead to the formation of a positive attitude toward the use of social media. 
The results indicate that team identification has a significant and positive effect on behavioral intentions through social media. This result is consistent with the researches of Gray \& Wert-Gray (2012) and Song \& Ryu (2016). Gray \& Wert-Gray (2012) have established that team identification has a relationship with behavioral intentions such as attendance, media consumption, purchase of team's promotional products, and word of mouth. When sports consumers have high team identification, they support their team by attending the games even when the team performs poorly (Wakefield \& Sloan, 1995). So, high team identification is a necessity for the supporters to preserve their relationship with the team. Cunningham \& Eastin (2017) have proven that a mental connection to the team can significantly predict a positive attitude toward the team. Therefore, the higher the individuals' team identification, the higher they are likely to have a positive attitude toward the team. In addition, mental connection to the team can significantly predict consumer behavior (Funk \& James, 2001). Thus, if individuals have a high sense of team identification, they will attend the games or watch them on television and purchase the team's apparel. Therefore, these individuals may actively participate on social media and use it to support their favorite teams (for example through electronic word of mouth and purchasing products).

Also, the results indicate that attitude toward social media has a significant and positive effect on behavioral intentions. In other words, individuals with a positive attitude toward social media -who are comfortable with it and use it a lot-are more likely to use social media to buy the team's promotional products, encourage and make suggestions to others to watch the team's games, and get more familiar with the financial supporters of their favorite team. This result is consistent with the research of Di Pietro, Di Virgilio \& Pantano (2012). Phang, Zhang \& Sutanto (2013) imply that participation in reading and providing content and discussion about particular products with other users on social media can increase the consumers' interest in the product and thus increase consumption intention. The attitude of individuals towards websites or social media is a good indication of their attitude toward the contents of those websites and social media. Gathering useful and reliable information from websites and social media increases the acceptance probability of these media (Cretti, 2015, p.11). Furthermore, enjoying social media relies on the nature of social networks providing new entertainments (Di Pietro, Di Virgilio \& Pantano, 2012). Therefore, individuals use social media for word-of-mouth advertising and purchasing the team's promotional products due to ease of access, perceived utility, reliability, pleasure, and a sense of comfort. 
In general, the obtained results confirm the conceptual model of the research and conform to the results of other studies conducted on the relationship between team identification, behavioral intentions, and consumer behavior with the traditional offline method. Accordingly, it can be stated that social media plays an important role as a novel method in sports consumption and the behavioral intentions of supporters and can be considered as a means for sports marketing. Supporters can have an active role in this process, which has multiple and mutual advantages. This promotion technique is cheaper than normal advertising; because it provides a direct and interactive connection with the target population and also provides the possibility of custom promotions. Therefore, it is suggested that Iranian sports club managers regard marketing methods on social media as a necessity, make an effort to develop them, and use the latent capacity of social media to develop and improve club fan bases and interact with them; which affects the behavioral intentions of consumers. An approach to that would be the creation and management of official pages and channels on social media by the clubs. This technique develops the connection between the clubs and their supporters and possibly increases their share in the market. Developing the relationship between the clubs and the supporters leads to the promotion of the supporters' team identification, which results in behavioral intentions (e.g. suggesting others to watch the games, purchasing products, getting to know the club's financial supporter, and electronic word of mouth). In addition, developing the supporters' team identification affects their attitude toward social media; in a way that they pursue the news, information and other content regarding the team through social media and actively participate in this field by providing content and giving opinions. Furthermore, sports clubs should take proper approaches to be able to manage the supporters in the virtual world, earn income from it (e.g. advertisements and broadcasting rights), and eradicate the neutral state of sports media consumption.

There are limitations in this study. The research statistical population only consists of sports sciences students; therefore, caution should be exercised when generalizing the results. It is preferable that future researches are conducted on different and larger statistical populations. In this research, the declarations of individuals are accepted; so it is preferred that future researches are conducted purposefully on individuals with active participation on the social pages of sports teams. Also, this research is a cross-sectional study and merely evaluates the behavioral intentions of individuals. It is suggested that future researches focus longitudinally on the actual behavior of individuals. 
Salari, M., \& Mazyari M. (2020). Social media and sport consumption: the effect of team identification on attitude and behavioral intention

\section{Acknowledgement}

We would also like to express our gratitude to the Vice-chancellor of Education and Research at University of Jiroft for their financial support.

\section{References}

Ashforth, B. E., \& Mael, F. (1989). Social identity theory and the organization. Academy of management review, 14(1), 20-39.

Billings, A. C., Qiao, F., Conlin, L., \& Nie, T. (2017). Permanently desiring the temporary? Snapchat, social media, and the shifting motivations of sports fans. Communication \& Sport, 5(1), 10-26

Cretti, C. (2015). Consumers' attitude towards social media advertising an empirical study. Unpublished BA Thesis, University of Fribourg, Fribourg.

Cunningham, N. R., \& Eastin, M. S. (2017). Second screen and sports: A structural investigation into team identification and efficacy. Communication \& Sport, 5(3), 288-310.

Pietro, L., Di Virgilio, F., \& Pantano, E. (2012). Social network for the choice of tourist destination: Attitude and behavioural intention. Journal of Hospitality and Tourism Technology, 3(1), 60-76.

Filo, K., Lock, D., \& Karg, A. (2015). Sport and social media research: A review. Sport management review, 18(2), 166-181. Fornell, C., \& Larcker, D. F. (1981). Evaluating structural equation models with unobservable variables and measurement error. Journal of marketing research, 18(1), 39-50.

Funk, D. C., \& James, J. (2001). The psychological continuum model: A conceptual framework for understanding an individual's psychological connection to sport. Sport management review, 4(2), 119-150.

Gau, L. S., James, J. D., \& Kim, J. C. (2009). Effects of team identification on motives, behavior outcomes, and perceived service quality. Asian Journal of Management and Humanity Sciences, 4(2-3), 76-90.

Gray, G. T., \& Wert-Gray, S. (2012). Customer retention in sports organization marketing: examining the impact of team identification and satisfaction with team performance. International Journal of Consumer Studies, 36(3), 275-281.

Heere, B., Walker, M., Yoshida, M., Ko, Y. J., Jordan, J. S., \& James, J. D. (2011). Brand community development through associated communities: Grounding community measurement within social identity theory. Journal of Marketing Theory and Practice, 19(4), 407-422. 
Salari, M., \& Mazyari M. (2020). Social media and sport consumption: the effect of team identification on attitude and behavioral intention

Katz, M., Ward, R. M., \& Heere, B. (2018). Explaining attendance through the brand community triad: Integrating network theory and team identification. Sport Management Review, 21(2), 176-188.

Lim, J. S., Hwang, Y., Kim, S., \& Biocca, F. A. (2015). How social media engagement leads to sports channel loyalty: Mediating roles of social presence and channel commitment. Computers in Human Behavior, 46, 158-167.

Lin, A., Gregor, S., \& Ewing, M. (2008). Developing a scale to measure the enjoyment of web experiences. Journal of Interactive Marketing, 22(4), 40-57.

Madrigal, R. (2001). Social identity effects in a belief-attitude-intentions hierarchy: Implications for corporate sponsorship. Psychology \& marketing, 18(2), 145-165.

Moyer, C., Pokrywczynski, J., \& Griffin, R. J. (2015). The relationship of fans' sports-team identification and Facebook usage to purchase of team products. Journal of Sports Media, 10(1), 31-49.

Mudrick, M., Miller, M., \& Atkin, D. (2016). The influence of social media on fan reactionary behaviors. Telematics and Informatics, 33(4), 896-903.

Park, J. A., \& Dittmore, S. (2014). The relationship among social media consumption, team identification, and behavioral intentions. Journal of Physical Education and Sport, 4(3), 331336.

Phang, C. W., Zhang, C., \& Sutanto, J. (2013). The influence of user interaction and participation in social media on the consumption intention of niche products. Information \& Management, 50(8), 661-672.

Phonthanukitithaworn, C., \& Sellitto, C. (2017). Facebook as a second screen: An influence on sport consumer satisfaction and behavioral intention. Telematics and Informatics, 34(8), $1477-1487$.

Pradhan, S. (2017). How You Like Me Now? The Influence of Athlete Behavior on Fan Group Dynamics and Sports Consumption. Unpublished doctoral dissertation, University of Michigan, Michigan.

Song, H. R., \& Ryu, W. Y. (2016). The Influence of Professional Baseball Fans Team Identification and Team Loyalty on Purchase Intention of Parent Company Products. Journal of Digital Convergence, 14(1), 445-452.

Suh, Y. I., Ahn, T., \& Pedersen, P. M. (2013). Examining the effects of team identification, eservice quality (e-SQ) and satisfaction on intention to revisit sports websites. International Journal of Sports Marketing and Sponsorship, 14(4), 2-19.

Trail, G. T., Fink, J. S., \& Anderson, D. F. (2003). Sport spectator consumption behavior. Sport Marketing Quarterly, 12(1), 8-17. 
Salari, M., \& Mazyari M. (2020). Social media and sport consumption: the effect of team identification on attitude and behavioral intention

Wakefield, K. L., \& Sloan, H. J. (1995). The effects of team loyalty and selected stadium factors on spectator attendance. Journal of sport management, 9(2), 153-172. 